227

Received: August 14, 2016

Accepted: October 19, 2016
Macedonian Journal of Animal Science, Vol. 6, No. 1, pp. 139-144 (2016)

In print: ISSN $1857-6907$

On line: ISSN $1857-7709$

UDC: $616.15: 615.357 .453 .036 .8]: 599.323 .4$

Original scientific paper

\title{
DEXAMETHASONE EFFECTS ON SERUM GLUCOSE AND POTASSIUM CONCENTRATIONS AND PLATELET COUNT OF WISTAR RAT
}

\author{
Muhamed Fočak, Edhem Hasković, Damir Suljević, Erna Islamagić \\ Department of Biology, Faculty of Science, \\ Zmaja od Bosne 33-35, Sarajevo, 71000 Bosnia and Herzegovina \\ mfocak10@gmail.com
}

\begin{abstract}
Dexamethasone is synthetic corticosteroide which influences the metabolism of glucose, ion transport in organisms and values of certain hematological parameters. In this research, dexamethasone was applied in musculus gluteus maximus of Wistar rat species in form of dexamethasone phosphate sodium solution in $1 \mathrm{~mL}$ ampoules. Each ampoule contains $4 \mathrm{mg}$ of dexamethasone, administered each 24 hours in 4 days period. Glucose and potassium concentrations in serum, and platelet count in whole blood were observed. After the experiment and statistical processing of collected data, it was determined that concentrations of serum glucose and platelet count were significantly increased, while values of serum potassium were significantly decreased, compared with control group.
\end{abstract}

Key words: corticosteroids; thrombocytopoiesis; hypokalemia; rats; glucose

\section{ВЛИЈАНИЕ НА ДЕКСАМЕТАЗОНОТ ВРЗ СЕРУМСКАТА ГЛУКОЗА, КОНЦЕНТРАЦИЈАТА НА КАЛИУМ И БРОЈОТ НА ТРОМБОЦИТИТЕ КАЈ СТАОРЦИ ОД СОJОТ WISTAR}

\begin{abstract}
Дексаметазонот е синтетички кортикостероид кој влијае на метаболизмот на глукозата, транспортот на јони во организмот и на вредноста на одредени хематолошки параметри. Во оваа испитување се аплицираше дексаметазон на лабораториски стаорци од сојот Wistar, во musculus gluteus maximus во форма на раствор на дексаметазон - натриум фосфат во ампули од $1 \mathrm{ml}$. Секоја ампула содржи $4 \mathrm{mg}$ дексаметазон, и се применуваше на секои 24 часа, во период од четири дена. Мерени се вредностите на серумската глукоза, калиумот и бројот на тромбоцити во полна крв. После експериментот и статистичката обработка на добиените податоци, утврдено е дека има значително зголемување на серумската глукоза и бројот на тромбоцитите, додека вредностите на калиумот во серумот, беа значително намалени во споредба со контролната група.
\end{abstract}

Клучни зборови: кортикостероиди, тромбоцитопоеза, хипокалиемија, стаорци, глукоза

\section{INTRODUCTION}

Dexamethasone (DX) is a fluoridated glucocorticosteroid with the strongest anti-inflammatory and immunosuppressive activity among drugs. After its introduction into organism, its bioavailability is $78 \%$. Its maximum serum concentration is reached after $10-30 \mathrm{mi}-$ nutes, and after 60 minutes it binds to albumins (68\%) Zhou \& Cidlowski [1]. At the cellular level, DX, similarly to natural glucocorticosteroids, binds to glucocorticosteroid receptor (GR), with molecular weight of $94 \mathrm{kDa}$, Duma et al. [2].
DX impacts metabolism of carbohydrates, proteins (increased catabolism of glucose, urea and uric acid in blood), activates lipolysis and changes body fat tissue redistribution. Parenteral intake of dexamethasone highly suppresses the central stress response system (hypothalamic - pituitary - adrenal axis), as well as secretion of cortisol, Levin \& Maibach [3]. Inhibition of cortisol releasing leads to carbohydrate metabolism change by increasing mobilization of gluconeogenic substrates that takes place in the liver, as well as decreased glucose utilization McMahon et al.; De Feo et al. [4, 5]. Synthetic glucocorticosteroids activate glucose metabolism in human liver, Pagano et al.; Rooney 
et al. [6, 7] while other authors demonstrated that glucocorticosteroids did not have such effect Malerbi et al.; Wajngot et al. [8, 9]. DX completely inhibits stimulatory effects of insulin, probably because of insulin's inability to maintain the level of fructose-2,6-phosphate, Rooney et al. [7]. Inhibition of insulin secretion leads to inactivation of enzyme pyruvate kinase, Klein et al. [10]. Application of synthetic steroids increases releasing of glucose from the cell, and its blood concentration. Considering that potassium transport is in relation to glucose transport, potassium ions also leave the cell, Malerbi et al.; Wajngot et al. [8, 9]. Also, DX decreases potassium ions absorption in gut and increases their excretion. Long term usage of DX may cause diseases as cataract or glaucoma, Bent et al. [11].

Dexamethasone acts as an antiemetic drug, inhibits the processes such as phagocytosis, lysosomal digestion, synthesis and releasing of cytokines and reduces the number of lymphocytes, eosinophils and monocytes. Synthetic corticosteroids, applied in a large dose have a high impact on occurrence of thrombocytopenia. In application, seven days after achieving the maximum value, platelets number was reduced, Kühne et al. [12]. Application of DX in concentration of $40 \mathrm{mg}$ a day was sufficient for an initial increase in the platelet count in adult rats, Andersen; Stasi et al. [13, 14].

In cases of adrenal insufficiency and Addison's disease, DX is prescribed for patients who do not tolerate prednisone or methylprednisolone, Charmandari et al. [15]. It is used in oncology in order to avoid side effects of chemotherapy treatment in cancer patients. DX is administered in cases of patients with spinal compression caused by tumour, Harousseau et al. [16].

In this research we examined the effects of dexamethasone on glucose and potassium ion serum concentrations, as well as its impact on platelet count in Wistar rats. It was important to determine side effects of dexamethasone in a dose used in the treatment of a wide variety of conditions in children and adolescents.

\section{EXPERIMENTAL SECTION}

Rattus norvegicus (Wistar species) lab rats used for this research were bred in the laboratory at the Department of Biochemistry and Physiology (Faculty of Science, University of Sarajevo). The acquisition, care, accommodation, use, and dispo- sition of rats in this research is in compliance with the international convention of American Psychological Association [17]. Serum potassium ions and glucose level were analysed, as well as platelet count in the control $(n=30)$ and experimental $(n=$ 30) group of animals. Both groups were of the same age (60 - 65 days) and had equal distribution of genders (14 males and 16 females).

Experimental design. Before the experiment, body mass was measured in order to determine adequate DX doses. Animals were anaesthetized with ethoxyethane before cardiopuncture. DX sodium phosphate solution in ampoules of $1 \mathrm{ml}$ (Dexason ${ }^{\circledR}$ Galenika a.d. Beograd) was used. One $\mathrm{ml}$ of this solution contains $4 \mathrm{mg}$ of DX sodium phosphate. Proper dose of dexamethasone was calculated by Clark's formula

$$
\left(\frac{\text { adult dose } \cdot \text { weight }(L b s)}{150}=\text { child dose }\right)
$$

DX was applied in musculus gluteus maximus every 24 hours for four days. Blood samples were collected in test tubes without anticoagulant for serum analysis, and for haematological analysis test tubes with heparin were used. Further samples were centrifuged on $3000 \mathrm{rpm}$ for 15 minutes in Heraeus - sepatech centrifuge.

Potassium concentration was determined by turbidimetric method in alkaline environment with tetraphenylborate (Potassium liquarapid, Human) and serum glucose by enzyme test with hexokinase (Glucose liquUV mono, Human). Spectrophotometer Spectronic 20 Genesys $^{\mathrm{IM}}$ was used for quantification. Measuring of platelet count was performed by Fonio's method, Adams [18].

Using IBM SPSS v.21 (IBM Corp., Armonk, NY, USA), statistical differences between the control and experimental group of rats treated with dexametasone were calculated by the $t$ test, ANOVA and Shapiro-Wilk W.

\section{RESULTS AND DISCUSSION}

Males and females in the control group had a higher average body weight than the experimental group. Males in both groups had higher values of weight than female rats. T-test and ANOVA showed statistically significant values between the compared groups $(\mathrm{p}<0.05)$. Shapiro-Wilk W test showed the presence of normal distribution of data (Table 1). 


\section{Table 1}

Estimated average values and statistical analysis of rats weight in both genders (males and females) and groups (control and experimental)

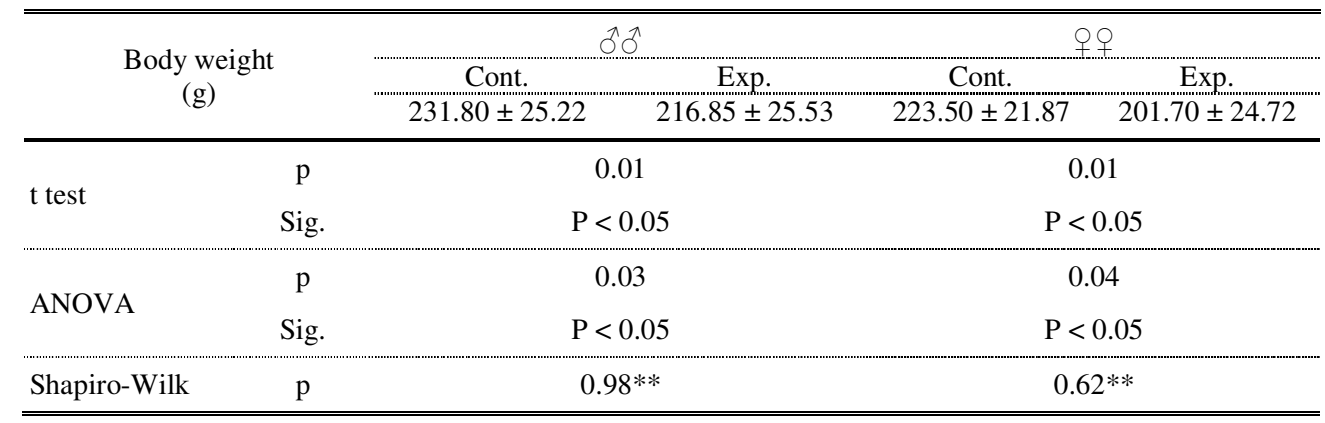

Results of analysed biochemical and haematological parameters in the control and experimental group are presented in Table 2. Among samples in the control group, small variations in potassium ion concentration were detected; however, a difference between two groups in platelet count was noticed.

High values of serum glucose concentration and increased platelet count were determined in the experimental group, while concentration of potas- sium was decreased. Low coefficient of variation showed significant difference in individual values of the analysed parameters. This was interpreted as an individual response to corticosteroid treatment (Table 2).

ANOVA showed that the obtained values of glucose and potassium concentration and platelets count in the experimental group are statistically significant in regard to the control group ( $\mathrm{p}<$ $0.01)$.

Table 2

The values of hematological and biochemical parameters in the control and experimental groups and statistical evaluation of analysed parameters

\begin{tabular}{|c|c|c|c|c|c|c|c|}
\hline \multirow{2}{*}{\multicolumn{2}{|c|}{ Statistical parameters }} & \multicolumn{2}{|c|}{ Glucose (mmol/L) } & \multicolumn{2}{|c|}{ Potassium (mmol/L) } & \multicolumn{2}{|c|}{ Platelets $\left(10^{9} / \mathrm{L}\right)$} \\
\hline & & Cont. & Exp. & Cont. & Exp. & Cont. & Exp. \\
\hline \multicolumn{2}{|l|}{ Mean value \pm SD } & $3.94 \pm 0.80$ & $11.44 \pm 2.75$ & $5.73 \pm 1.97$ & $2.71 \pm 0.73$ & $898.20 \pm 62.35$ & $1197.15 \pm 96.10$ \\
\hline \multicolumn{2}{|l|}{ Minimum value } & 2.26 & 6.40 & 2.40 & 1.57 & 789.00 & 1070.00 \\
\hline \multicolumn{2}{|l|}{ Maximum value } & 4.86 & 19.70 & 8.16 & 4.09 & 1005.00 & 1366.00 \\
\hline \multicolumn{2}{|l|}{ LCL } & 3.47 & 10.15 & 4.63 & 2.36 & 863.66 & 1152.17 \\
\hline \multicolumn{2}{|l|}{ UCL } & 4.41 & 12.72 & 6.83 & 3.05 & 932.73 & 1242.12 \\
\hline \multicolumn{2}{|l|}{ Skewness } & -0.94 & 0.96 & -0.35 & 0.02 & 0.02 & 0.58 \\
\hline \multicolumn{2}{|l|}{ Kurtosis } & 2.79 & 5.35 & 1.66 & 2.20 & 2.33 & 1.96 \\
\hline \multicolumn{2}{|c|}{ Coefficient of variation } & 21.97 & 24.05 & 34.38 & 27.03 & 6.94 & 8.03 \\
\hline \multirow{2}{*}{ t-test } & $\mathrm{P}$ & \multicolumn{2}{|c|}{0.000} & \multicolumn{2}{|c|}{0.000} & \multicolumn{2}{|c|}{0.000} \\
\hline & Sig. & \multicolumn{2}{|c|}{$\mathrm{p}<0.01$} & \multicolumn{2}{|c|}{$\mathrm{p}<0.01$} & \multicolumn{2}{|c|}{$\mathrm{p}<0.01$} \\
\hline \multirow{2}{*}{ ANOVA } & $\mathrm{P}$ & \multicolumn{2}{|c|}{0.001} & \multicolumn{2}{|c|}{0.001} & \multicolumn{2}{|c|}{0.000} \\
\hline & Sig. & \multicolumn{2}{|c|}{$\mathrm{p}<0.01$} & \multicolumn{2}{|c|}{$\mathrm{p}<0.01$} & \multicolumn{2}{|c|}{$\mathrm{p}<0.01$} \\
\hline Shapiro-Wilk W & $\mathrm{P}$ & \multicolumn{2}{|c|}{$0.42^{*}$} & \multicolumn{2}{|c|}{$0.06^{*}$} & \multicolumn{2}{|c|}{$0.03^{* *}$} \\
\hline
\end{tabular}

LCL - lower control limit, UCL - upper control limit, ${ }^{*}$ data are normally distributed, ${ }^{* *}$ rejected null hypothesis 
When biochemical and haematological parameters of both examined groups were compared, it was noticeable that after dexamethasone application there was a large increase of glucose concentration and decrease of potassium concentration, while platelet count was very high in the experimental group $(\mathrm{p}<0.001)$. Shapiro-Wilk $\mathrm{W}$ test showed the presence of normal distribution of analysed parameters for individual cases, while platelet count values showed larger variations from normal distribution (Table 2).

Pearson's coefficient indicated signifycantly negative correlation between glucose and potassium concentration, meaning that increase in glucose concentration was followed by decrease in potassium concentration.

Application of DX for a period of four days resulted in clearly observable changes in biochemical and haematological parameters in rat blood. Intramuscular injection of DX had a high impact on glucose metabolism and its homeostasis. In general, in Wistar rats, low serum glucose values were determined $\mathrm{Xu}$ et al. [19]. This could be explained by high muscle metabolism, and therefore high rate of glycollisis which correlates with decreased level of serum glucose. Application of dexamethasone results in increase of serum glucose values from $3.94 \mathrm{mmol} / \mathrm{l}$ to $11.4 \mathrm{mmol} / \mathrm{l}$, because of the influence on gluconeogenetic pathway in the liver, wherefore glucose utilisation in cells is reduced, McMahon et al.; De Feo et al. [4, 5]. Other studies show antagonistic effect in regard to corticosteroids and insulin, where peripheral uptake of glucose is inhibited and gluconeogenesis is triggered, Wang et al. [20]. Similar results were established by authors Olefsky; Hans et al. [21, 22].

Glucose and potassium ions share the same metabolic pathways. During an increased glucose concentration, potassium-dependent channels are activated and potassium ions are secreted into blood. This results in higher overall potassium concentration in blood and thereafter its secretion in renal tubule with ketone bodies, Olsson \& Kallner [23]. When taking synthetic corticosteroids, glucose blood concentration increases because glucose leaves the cells. Considering that potassium transport is dependent on glucose transport, potassium also leaves the cells.

Potassium concentration levels $(5.73 \mathrm{mmol} / \mathrm{l})$ in the control group of rats were higher compared to results of author Woldow [24], yet similar to the research of authors Zorbas et al. [25] in rats with hypokinesia, and results of authors Bia et al. [26]. Because of related metabolic pathways of glucose and potassium, decrease in concentration of serum potassium ions in the experimental group of rats was observed $(2.71 \mathrm{mmol} / \mathrm{l})$. Klein et al. [10] also show that after intraperitoneal application of dexamethasone, excretion of potassium ions by kidneys was excessive with similar values in statistical significance.

Glucocorticoids induce a rapid natriuresis and kaliuresis in rodents Marissal-Arvy \& Mormede; Muller et al.; Campen et al. [27, 28, 29]. The effect of DX on $\mathrm{Na}^{+} / \mathrm{K}^{+}$pump subunit expression and muscle exchange of $\mathrm{K}^{+}$during exercise in humans was investigated, Nordsborg et al. [30]. The results indicate that an increased $\mathrm{Na}^{+} / \mathrm{K}^{+}$pump expression per se is of importance for thigh $\mathrm{K}^{+}$reuptake at the onset of low and moderate intensity exercise, but less important during high intensity exercise.

DX inhibits synthesis and excretion of a large number of interleukins (among them IL-3 has important role in thrombocytopoiesis). Otherwise, it has a high impact on thrombopoietin production and secretion, and this glycoprotein has a positive effect on thrombocytopoiesis. Platelet number in the control group of rats $(898.2 \cdot 109 / 1)$ is similar to the results observed in the research by Bourchier \& Weston [31]. DX application leads to statistically significant increase in platelet count. In the research of authors Andersen; Stasi et al. [13, 14], it is reported that the application of dexamethasone in concentration of $40 \mathrm{mg} /$ day is sufficient only for initial increase of platelet count in adult rats. DX positively affects gene activation responsible for thrombopoietin synthesis.

To determine the mechanism by which platelet counts increase after corticosteroid therapy for human immune thrombocytopenic purpura (ITP), Mizutani et al. [32] studied the platelet kinetics using prednisolone - treated ITP-prone mice, (NZW x BXSB) F1. These results suggest that corticosteroids improve platelet counts not only by suppressing systemic reticulo-endothelial phagocytic function, but also by reducing antibody production.

Based on the statistically processed data and analysis of the results of biochemical and haematological parameters, it can be concluded that DX significantly affects the concentration of biochemical (glucose and potassium) and haematological (platelet count) parameters after four days of application in the dose calculated by Clark's formula. 


\section{REFERENCES}

[1] Zhou, J., Cidlowski, J.A.: The human glucocorticoid receptor: One gene, multiple proteins and diverse responses. Steroids, 70, 407-417 (2005).

[2] Duma, D., Jewell, C.M., Cidlovski, J.A.: Multiple glucocorticoids receptor isoformes and mechanisms of post translational modification. J. Steroid. Biochem. Mol. Biol., 102, 11-21 (2006).

[3] Levin, C., Maibach, H.I.: Topical corticosteroid - induced adrenocortical insuffiency: clinical implications. Am. $J$. Clin. Dermatol., 3, 141-147 (2002).

[4] McMahon, M., Gerich, J. Rizza, R.: Effects of glucocorticosteroids on carbohydrate metabolism. Diabetes Metab. Res. Rev., 4, 17-30 (1988).

[5] De Feo, P., Parriello, G., Torlone, E., Ventura, M. M., Fanelli, C., Santeusanio, F., Brunett, P., Gerich, J. E., Bolli, G. B.: Contribution of cortisol to glucose counter regulation in humans. Am. J. Physiol., 257, 35-42 (1989).

[6] Pagano, G., Cavallo-Perin, P., Cassader, M., Bruno, A., Ozzello, A., Masciola, P., Dall'omo, A. M., Imbimbo, B.: An in vivo and in vitro study of the mechanism of prednisone - induced insulin resistance in helathy subjects. $J$. Clin. Invest., 72, 1814-1820 (1983).

[7] Rooney, D. P., Neeley, R. D., Cullen, C., Ennis, C. N., Sheridan, B., Atkinson, A. B., Timble, E. R., Bell, P. M.: The effect of cortisol on glucose/glucose-6-phosphate cycle activity and insuline action. J. Clin. Endocrinol. Metab., 77, 1180-1183 (1993).

[8] Malerbi, D., Liberman, B., Giurno-Filho, A., GianellaNeto, D., Wajchenberg, B. L.: Glucocorticoids and glucose metabolism hepatic glucose production in untreated addisonian patients and on two different levels of glucocorticosteroid administration. Clin Endocrinol., 28, 415422 (1988).

[9] Wajngot, A., Khan, A., Giacca, A., Vranić, M., Efendić, S.: Dexamethasone incerases glucose cycling, but not glucose production, in healthy subjects. Am. J. Physiol., 259, 626-632 (1990).

[10] Klein, H., Ullman, S., Drenckhan, M., Grimmsmann, T., Unthan - Fechner, K., Probst, I.: Differential modulation of insulin actions by dexamethasone: studies in primary cultures of adult rat hepatocytes. J. Hepato., 37, 432-440 (2002).

[11] Bent, S. J., Pierson J. D., Forney, L. J.: Measuring species richness based on microbial community fingerprints: the emperor has no clothes. Applied and Environmental Microbiology., 73, 2399-2401 (2007).

[12] Kühne, T., Freedman, J., Semple, J., Doile, J., Butchrat, S., Blanchette, V.: Platelet and immune responses to oral cyclic dexamethasone therapy in childhood chronic immune thrombocytopenic purpura. J. Pediatr., 130, 17-24 (1997).

[13] Andersen, J. C.: Response of resistant idiopathic thrombocitopenic purpura to pulsed high-dose dexamethasone therapy. N. Engl. J. Med., 330, 1560-1564 (1994).

[14] Stasi, R., Brunetti, M., Pagano, A.: Pulsed intravenous high-dose dexamethasone in adults with chronic idiopathis thrombocitohenic purpura. Blood. Cells. Mol. Dis., 26, 582-586 (2000).
[15] Charmandari, E., Kino, T., Ichijo, T., Chrousos, G. P.: Generalized Glucocorticoid Resistance: Clinical Aspects, Molecular Mechanisms, and Implications of a Rare $\mathrm{Ge}-$ netic Disorder. J. Clin. Endocrinol. Metab., 93, 1563 1572 (2008).

[16] Harousseau, J. L., Attal, M., Leleu, X., Troncy, J., Pegourie, B., Stoppa, A.M., Hulin, C., Benboubker, L.: Bortezomib plus dexamethasone as induction treatment prior to autologous stem cell transplantation in patients with newly diagnosed multiple myeloma: results of an IFM phase II study. Haematologica., 91, 1498-1505 (2006).

[17] American Psychological Association.: Guidelines for Ethical Conduct in the Care and Use of Nonhuman Animals in Research. Retrieved February 24, 2012 (2012).

[18] Adams, E.: A Method for Counting Blood Platelets in Small Animals. Yale J. Biol. Med., 21, 17-20 (1948).

[19] Xu, D., Dhillon, A., Davey, C., Fournier, P., Palmer, T.N.: Alcohol and glucose metabolism in skeletal muscles in the rat. Addict Biol., 1, 71-83 (1996).

[20] Wang, A. A., Douglas, T., Hutchinson, M. D.: The effect of corticosteroid injection for trigger finger on blood glucose level in diabetic patients. J. Hand. Surg., 31, 979981 (2006).

[21] Olefsky, J. M.: Effect of dexamethasone on insulin binding, glucose transport, and glucose oxidation of isolated rat adipocytes. J. Clin. Invest., 56, 1499-1150 (1975).

[22] Hans, P., Vanthuyne, A., Dewandre, P. Y., Brichant, J. F., Bonhomme, V.: Blood glucose concentration profile after $10 \mathrm{mg}$ dexamethasone in non-diabetic and type 2 diabetic patients undergoing abdominal surgery. Br. J. Anaesth., 97, 164-170 (2006).

[23] Olsson, U., Kallner, A.: Effects of starvation and of selenium deficiency on the urinary excretion of electrolytes, ketone bodies, creatinine, urea and uric acid. J. Trace Elem. Med. Biol., 9, 88-93 (1995).

[24] Woldow, N.: Serum potassium levels and adrenal hypertrophy in rats (Rattus norvegicus), infected by Tripanosoma lewisi. J. Wildl. Dis., 5, 297-301 (1969).

[25] Zorbas, Y. G., Kakurin, V. J., Afonin, V. B., Denogradov, S. D., Yarullin, V. L.: Magnesium deposition and depletion in magnesium supplemented rats during and after hypokinesia and vivarium control. Biol. Trace Elem. Res., 86, 203-16 (2002).

[26] Bia, M. J., Tyler, V., Defronzo, R.: The effect of dexamethasone on renal potassium excretion and acute potassium tolerance. Endocrinology, 113, 1690-1696 (1983).

[27] Marissal-Arvy, N., Mormede, P.: Excretion of electrolytes in Brown Norway and Fischer 344 rats: effects of adrenalectomy and of mineralocorticoid and glucocorticoid receptor ligands. Exp. Physiol., 89, 753-65 (2004).

[28] Muller, O. G., Parnova, R. G., Centeno, G., Rossier, B. C., Firsov, D., Horisberger, J. D.: Mineralocorticoid effects in the kidney: correlation between alphaENaC, GILZ, and Sgk - 1 mRNA expression and urinary excretion of $\mathrm{Na}^{+}$and $\mathrm{K}^{+, .}$Clin. J. Am. Soc. Nephrol., 14, 1107 15 (2003).

[29] Campen, T. J., Vaughn, D. A., Fanestil, D. D.: Mineralo and glucocorticoid effects on renal excretion of electrolytes. Pflugers Arch., 399, 93-101 (1983).

[30] Nordsborg, N., Ovesen, J., Thomassen, M., Zangenberg, M., Jøns, C., Iaia, F. M., Nielsen, J. J., Bangsbo, J.: Effect 
of dexamethasone on skeletal muscle $\mathrm{Na}^{+}, \mathrm{K}^{+}$pump subunit specific expression and $\mathrm{K}^{+}$homeostasis during exercise in humans. J. Physiol., 586. 5, 1447-1459 (2008).

[31] Bourchier, D., Weston, P. J.: The effect of dexamethasone upon platelets and neutrophils of preterm infants with chronic lung disease. Paediatr. Child. Health., 27, 101-104 (1991).
[32] Mizutani, H., Furubayashi, T., Imai, Y., Kashiwagi, H., Honda, S., Take, H., Kurata, Y., Yonezawa, T., Tarui, S., lkehara, S.: Mechanisms of Corticosteroid Action in Immune Thrombocytopenic Purpura (ITP): Experimental Studies Using ITP - Prone Mice, (NZW X BXSB) F1. Blood., 179, 942 - 947 (1992). 